УДК 78.03 : 78.071 .1 (439) (092) : 780.616 .432

DOI 10.34064/khnum1-5703

\title{
Геді Анастасія
}

ORCID 0000-0001-7485-5712

Національна музична академія музики імені П. І. Чайковського, 01001 вул. Архітектора Городецького 1-3/11, Київ, Украӥна

\section{ЕВОЛЮЦІЯ ФОРТЕПІАННОГО СТИЛЮ БЕЛИ БАРТОКА}

\section{АНОТАЦІЯ • Геді А. Еволюція фортепіанного стилю Бели Бартока.} Досліджується виконавська складова творчості Б. Бартока-піаніста, що попри вивченість багатьох аспектів його діяльності, до нині залишається без спеціального аналізу. Український слухач знайомий з обмеженим колом творів Б. Бартока, тому акцентуація виконавської діяльності митця слугує додатковим стимулом актуалізаціїйого мистецтва в наш час. Існує певна кількість творів, написаних досить традиційно, в класичному ключі. У цих творах Б. Барток досить скупо використовує колористичні можливості фортепіано (широкий охват регістрів, педальні ефекти), яскравим прикладом $\epsilon$ «Румунські народні танці» ор. 8-a. Констатуємо «накладення» класичної традиції, і нових течій, пов'язаних з ударним розумінням фортепіано. 3 точки зору часової організації його твори відрізняє широке використання репетиційної техніки, прийомів ostinato, метрична змінність, поліритмія. Відзначені віхові твори фортепіанної еволюції стилю митця: Рапсодія, цикли «Румунські народні танці», гранично складні в піаністичному відношенні «Етюди» ор. 18 як зразок експресіоністської естетики.

Більшість фортепіанних творів Б. Бартока були написані в ранній і експериментальний періоди творчості. Простежено «схильність» Б. Бартока до первинних і романтичних жанрів, програмної циклічності; незмінний інтерес до творення дитячого репертуару (задля популяризація народної музики і залучення дітей до нової музичної мови). В цілому еволюцію фортепіанного стилю Б. Бартока можна розглядати як рух від романтичної (через фольклоризм) до неокласичнї традиції, що проявляється в зміні музично-мовних ресурсів (ритм, гармонія, особливості організації музичної форми, фактура, 
мелос). Як наслідок, змінювався і звуковий образ фортепіано. Засаднича якість фортепіанного стилю митця - національна характерність, оповита ресурсами новітньої техніки музичної композиції. Слуховий аналіз виконавського стилю Б. Бартока дозволив зробити висновок, що на відміну від багатьох піаністів романтичної традиції, Б. Барток дуже помірно користується педальними ефектами, віддаючи перевагу ясному і чіткому промовлянню всіх елементів фактури. Отже, фортепіанне письмо Бели Бартока $є$ увиразненням новаційного мислення митця, в якому виконавська складова його власних можливостей відігравала ключову роль. • Ключові слова: твори Бели Бартока, фортепіанний стиль, композиторське письмо.

\section{ABSTRACT $\bullet$ Gedi A. The evolution of B. Bartok's piano style.}

Subject actuality. The article highlights the evolution of the compositional style of the Hungarian composer, taking into account the performance component of Bartok as a pianist. Based on existing musicological sources (works by A. Alekseev, B. Sabolcha, S. Sigitov, J. Uyfalushi, I. Martynov, I. Nestev, A. Malinkovskaya) the historical periodization of the general interest in Bartok's work is indicated. Despite the study of many aspects of his creative activity, the performance of B. Bartok still remains without special analysis. Therefore, the process of studying the work of B. Bartok today can not be considered completed. The issues of interaction between the compositional and performance style of B. Bartok, modern interpretations of his works remain opened. The Ukrainian listener is familiar with a limited range of B. Bartok's works, so the emphasis on the artist's performance serves as an additional stimulus for the actualization of his art in our time.

The main presentation of the material. The evolution of $B$. Bartok's piano style was identified as a problem by L. Gakkel through the constituent parameters of the piano style: 1) the "realistic-non-pedal" sound image of the piano; 2) coloristic shock-noise method of sound construction; 3) textured accentuated tone as a tonal-harmonic ground. Indeed, many works of the composer testify to this interpretation of the piano: "Two elegies op. $8 / \mathrm{b}$, Burlesque three pieces op. 8c, Suite op. 14, Etudes op. 18, Sonata; three concertos for piano and orchestra. However, there are a number of works written quite traditionally, in the classical key. In these works B. Bartok uses the coloristic possibilities of the piano quite avariciously (wide range of registers, pedal effects), a striking example is the "Romanian folk dances" op. 8-a). 
Milestones of the piano evolution of the artist's style are marked: Rhapsody, cycles "Romanian folk dances". Etudes op. 18 -a sample of expressionist aesthetics, extremely complex in pianistic terms. They use extreme technical difficulties that require maximum arm stretching and great physical strength.Most of Bartok's piano works were written in the first two creation periods - early and experimental. The composer's attention was focused on three genre areas: folklore, pedagogics, innovation. The communicative semantics of these spheres, of course, influenced the composer's decisions in the formative field, texture, piano technique, the level of virtuosity. The regularities are traced: B. Bartok's "commitment" to primary (song and dance) and romantic genres (elegy, rhapsody, rich people), program cyclicity; constant interest in creating a repertoire for children, which solves two tasks at once: the promotion of folk music and the children involvement into a new musical language.

Note as a contradiction the fact that the analysis of the works of B. Bartok, created in the first and second period, does not fully confirm the version of L. Gakkel, about a radicalistic change in the sound image of the piano. Probably, in B. Bartok's work the new did not exclude the old one. The basic quality of B. Bartok's piano style is its national characteristic, which is shrouded in the resources of the latest technique of musical composition.

Conclusions. B. Bartok-pianist by genotype belongs to the Liszt's branch of European pianism. The Liszt's tradition is a combination of classical-romantic performing principles, which is especially evident in the works of disciples and followers of F. Busoni, K. Martinsen, K. Arrau, and G. Gould. In general, the evolution of B. Bartok's piano style can be seen as a movement from the romantic - through folklore - to the neoclassical tradition, which is manifested in the change of musical-linguistic resources (rhythm, harmony, features of musical form, texture, melody). As a result, also the sound image of the piano was being changed.

Auditory analysis of B. Bartok's performing style allowed us to conclude that, unlike many pianists of the romantic tradition, B. Bartok uses pedal effects very avariciously, preferring clear and precise pronunciation (utterance) of all elements of the texture. We state the «imposition» of the classical tradition, which originates from harpsichordists, and new trends associated with the percussive understanding of the piano.

From the point of view of the temporal organization of the musical form, his works are distinguished by metrical variability and polyrhythm; rhythmic 
discrepancy of textured layers; extensive use of repetition techniques and ostinato techniques. The foundations of Bartok's mode-harmonic mentality (reliance on ancient modes of folk music; mode variability in the conditions of chromatic tonality) determine the difficulties of mastering the «intonation dictionary» of his piano works, and in general the technical equipment of the texture. Thus, Bela Bartok's piano writing style is an expression of the artist's innovative thinking, in which the performing component of his own abilities played a key role. • Key words: works by B. Bartok, piano style, compositional writing.

Актуальність теми. Бела Барток - визнаний класик музичного мистецтва XX століття. Втім, коли звертаєшся до сучасних експансій його творів в репертуарі піаністів, розумієш, наскільки цей багатогранний музикант, чия творча еволюція вражає могутньою силою авторського самовираження в багатьох напрямах, залишається для України в певному сенсі «невідомим». Сучасники композитора поцінювали його за відкриття фольклору різних слов'янських народів, що Б. Барток привніс у європейську культуру. При цьому він добре знав композицію за системою А. Шенберга і був видатним виконавцем, одним з найбільш самобутніх піаністів XX ст. В юні роки він мав вплив блискучого угорського піаніста-композитора Ерно Донаньї (1877-1960). Особливу значну роль в художньому і суто піаністичному розвитку Б. Бартока зіграв його вчитель в Будапештській академії музики професор Іштван Томан (1862-1940), учень Ф. Ліста, видатний піаніст-педагог кілька поколінь чудових піаністів (Е. Донаньі, I. Кеері-Санто, А. Секей, І. Унгар). Він займався виконавською діяльністю все життя: давав сольні концерти в Будапешті та Парижі, Базелі, Франкфурті-на-Майні, виступав 3 найкращими диригентами, в камерних ансамблях зі скрипалем Йожефом Сігеті, іншими видатними інструменталістами. В останні роки життя разом зі своєю другою дружиною, піаністкою Дітте Пасторі. Барток концертував Європою і США. Тріо для кларнета і фортепіано «Контрасти» виконане з Йозефом Сігеті і Бені Гудман прозвучало в 1939 році у Нью-Йорку.

Український слухач знайомий з обмеженим колом творів цього видатного майстра. Цікаво, що Барток приїздив до Харкова в якос- 
ті концертуючого піаніста та виконував власні твори ${ }^{1}$ (в рамках гастролей в СРСР). Отже, його шлях починався з кар'єри піаніста; тож не дивно, що саме його постать була однією з найбільш впливових щодо творення «образу фортепіано» XX століття. Однак виконавська постать Б. Бартока-піаніста до нині залишається без спеціального аналізу. Так, А. Малінковська (1985) застерігає від спрощеного погляду на стиль гри Б. Бартока: «...яким гостродинамічним, сучасним духом просякнуто трактовка Бартоком сонат Скарлатті, не кажучи вже про бетховенську музику!» I далі стосовно впливу виконавства на композицію: «...ударність бартоківського піанізму - складний и багатий звукокрасочний комплекс. Обов'язковими елементами $<\ldots>\epsilon$ своєрідна вібрація гармонічної фарби та секундовий компонент в акордиці (аж до суцільних кластерів)» (А. Малінковська: с. 9).

$€$ окремі зауваження, які ставлять під сумнів визначення його фортепіанного стилю як «беспедально-ударний», за Л. Гаккелем (1976). Дійсно, багато творів композитора свідчать про подібну трактовку фортепіано: «Дві елегії ор. 8/b (1908-1909), Бурлески-три п’єси ор. 8c (1908-1911), Сюїта ор. 14 (1916), Етюди ор. 18 (1918), Соната (1926); три концерти для фортепіано з оркестром (1926, 1931, 1945). Однак є певна кількість творів, написаних досить традиційно, в «класичному» стилі. У них Б. Барток досить скупо використовує колористичні можливості фортепіано (широкий охват регістрів, педальні ефекти). Яскравим прикладом є «Румунські народні танці» ор. 8-a. Музикознавче осягання творчості Б. Бартока не $є$ завершеним. Наукове обгрунтування значення виконавської діяльності в контексті еволюції композиторського стилю слугує додатковим чинником акmyалізації його мистецтва в наш час.

Мета дослідження - простежити еволюцію фортепіанного стилю Бартока з урахуванням виконавської складової його творчості.

\footnotetext{
1 Авторські концерти Б. Бартока відбулися 1929 року - у Харькові 6 січня, в Одесі 9 січня, Санкт-Петербурзі 16 січня та у Москві 24 січня, де він виконував як власні твори (15 угорських пісень, Бурлески, Румунські колядки, Allegro barbaro), так і інших композиторов (3. Кодаї, Б. Марчелло, Л. Россі, Д. Скарлатті), маючи великий успіх у публіки.
} 
Аналіз публікацій затемою. Музикознавчі джерела 3 «бартокознавства» можна умовно поділити на етапи. Так, 20-40-ті роки позначені критичними рецензіями сучасників композитора та дослідників (Б. Асаф'єв, В. Бєляєв, А. Буш, Е. Веллес, В. Каратигін, М. Мясковський, М. Равель), які мали змогу з ним особисто спілкуватися, чути його твори, в тому числі в авторському виконанні (за: I. Нєстьєв: 782-783). Спроби цілісної характеристики життєтворчості митця в жанрі монографії відбулись лише у 60-70-ті роки (І. Мартинов, 1956; 1968; Б. Сабольчі, 1963; Й. Уйфалуши, 1965; І. Нєстьєв, 1969; С. Сігітов, 1971). У наступні 30 років до творів Бартока звертаються поціновувачі окремих ознак його новаторського мислення (I. Чижик, 1981; Е. Деревянченко, 2005; О. Андрєєва, 2013).

Виклад основного матеріалу. Біографи композитора вказують, що перші твори для фортепіано Барток написав у віці дев'яти років (Вальс, Мазурка, Полька). Статус першого опусу отримала тільки Рапсодія 1904 року створення, згодом перероблена композитором для виконання з оркестром і звана в листах композитора «Konzertstück». Є дані про авторське виконання Рапсодії ор. 1 в серпні 1905 року в Парижі на конкурсі імені Антона Рубінштейна, де Б. Барток представляв свій твір 3 оркестром Ламуре під керуванням Камілла Шевійяра, французького композитора, віолончеліста і члена журі конкурсу, та був удостоєний диплома. Саме для конкурсу він зробив перекладення для фортепіано з оркестром. Отже, можна констатувати наявний романтичний орієнтир молодого композитора. Як і романтики, Б. Барток вважав за краще працювати в циклічних формах. Вони переважають за кількістю в порівнянні з іншими формами фортепіанної творчості («Багателі», «Ескізи», «Траурні пісні», «Бурлески», «Імпровізації», «На вільному повітрі», Три рондо»).

На початку професійної освіти Б. Барток-піаніст належав до лістовської «гілки» європейського піанізму, представники якої вважали рояль аналогом оркестру з великими тембро-динамічними можливостями. Коли Ф. Ліст зробив переклад для фортепіано усіх бетховенських симфоній, то цим він наголосив себе продовжувачем класичної традиції. Отже, лістовська виконавських традиція виявилася з'єднанням класико-романтичних принципів, що особливо яскраво 
простежується у творчості учнів і послідовників славетного генія угорської музики (Ф. Бузоні, К. Мартінсен, К. Аррау, Г. Гульда).

До речі, існує запис 1940 року «Крейцерової» сонати Л. Бетховена у виконанні Б. Бартока та Й. Сігеті, що підтверджує належність Бартока-піаніста до класичної традиції (на певному етапі). Оскільки двох музикантів пов'язувала багаторічна творча дружба і вони багато грали разом, ясно, що інтерпретація бетховенської сонати демонструє «дует однодумців». Б. Барток наче свідомо обирає роль співтворця, не змагаючись зі скрипалем. Партія фортепіано звучить ніби приглушено: ясно, темброво і ритмічно окреслено, але ніколи не врівень зі скрипкою. Можна ясно відчути фірмовий бартоковській звуковий стиль, що виявляється в ритмічної пружності, регістровому різноманітності звучання, характерному гострому туше.

За Л. Гаккелем, еволюція фортепіанного стилю митця складалася так: 1897-1908 - ранній стиль, що поєднує романтичні та фольклорні ознаки;

1908-1914 - ствердження ударно-беспедального піанізму;

1914-1917 - перші кроки до неокласицизму;

20-і роки - поліфонічний реально-беспедальний піанізм;

30-і роки - тенденція до синтезу2

У цій періодизації є дивовижна «лакуна» - 1918 рік. Саме тоді були написані «Етюди ор. 18», котрі І. Нестьєв (1969) вважав модерновим проявом національного стилю, а Л. Гаккель (1976) відносив до неокласицизму, з чим не можна погодитися. Цикл з трьох етюдів, дотриманих у певному фактурному і темповому форматі, є одним 3 найбільш експресіоністських опусів Б. Бартока. Перший (Allegromolto) має інтервальну будову з чергувань малої нони, великої секунди та малої терції в горизонтальних проєкціях. Особливе значення має регістровий контраст: розташування голосів по зонам в межах чотирьох октав, прийом «чорно-білої» фактури та гра в «три руки» в середньому розділі п'єс.

\footnotetext{
2 Симптоматично, що в останній період творчості, далеко від батьківщини Барток створив тільки один фортепіанний твір - Третій концерт для фортепіано з оркестром, в якому всі творчі інтенції композитора об'єднуються в новий стильовий синтез (неокласицизм) з елементами ностальгії за «вербункошем».
} 
Етюд № 2 (Andantesostenuto) - більш традиційний за фактурним викладом: мелодичний голос, оповитий фігураціямив умовах бартоковської ладогармонії. Третій етюд (Rubato) - витончене капричіо, де можна виявити динамічне і темпоритмічне розмаїття. У ньому експонована звукова структура - «акорд Бартока» ${ }^{3}$ (термін Е. Лендваї) він став наповненням як фонових, так і мелодійних голосів (горизонтально і вертикально). Характерними є метро-ритмічні формули 10/16, 9/16, 11/16. На особливу увагу заслуговує акцентування мелодії в умовах поліметрії 2/8, 3/8, 4/8. Отже, стилістику Етюдів ор. 18 Б. Бартока створює метро-ритмічнаі ладо-гармонічна специфіка. До ускладнень музичної мови слід віднести незвичні групування в різних голосах (квінтолі, секстолі, септолі), перманентну зміну метру $(10 / 16,11 / 16,15 / 16,7 / 8,9 / 16)$, нашарування формулв різних пластах фактури.

Етюди ор. 18 гранично складні в піаністичному відношенні. У них застосовані крайні технічні складності, що вимагають максимального розтягування рук і великої фізичної сили: унісон руху обох рук з висхідними і спадними стрибками на нону, деціму, відпрацювання хвилеподібних арпеджійованих пасажів, накладання фактурних шарів, складні поєднання горизонтальних і вертикальних проекцій теми, яка трансформується акордова техніка. 3 одного боку, Етюди Б. Бартока продовжують традицію концертних етюдів Ф. Ліста, Ф. Шопена, К. Дебюссі, де задум композитора не зводиться тільки до технічних вправ. 3 іншого - в них закладена інша естетика звуку, простежується вплив творчості А. Шенберга з його ранніми творами (Три п'єси ор. 11). У них він почерпнув для себе прийоми безперервних «інверсій», опору на дисонанси в умовах відсутності тональності.

Стосовно виконання цього опусу існує дуже мало фактів. Барток ïх зіграв у Будапеште 21 квітня 1919 року. Із сучасних - запис ор. 18 відомим угорським піанистом Золтаном Кочишем.

3 У складі цього акорду - мала терція - чиста кварта - мала терція, або інші септакордові структури (мала секунда - мала терція, мала терції - чиста кварта, мала секунда - чиста кварта). 
Серед фольклорних праць Б. Бартока вирізняється капітальна збірка румунських колядок (вийшла друком 1935 р., у Відні), що налічує 484 старовинних обрядових наспіви. 3 них композитор відібрав 20 i на їх основі створив цикли «Румунські колядки» $\mathrm{i}$ «Румунські різдвяні пісні», які $є$ цікавими з точки зору еволюції фортепіанного стилю. Кожна серія мініатюр складається 310 п'єс, що без цезур змінюють одна одну. На особливу увагу заслуговує метроритм «Румунських колядок». Лише менша частина витримана у звичних для танцювальних мелодій дводольних розмірах з повторюваним чергуванням сильних і слабких долей (№№ 5, 9 в першій серії, №№ 1, 4, 5, 7, 8 - у другій). У більшості ж п'єс застосовуються складні чергування дво- і тридольних розмірів, або змішані: 5/8, 7/8.

Особливо цікаві комбінації з вісімок, близькі до болгарських ритмів, що діляться на нерівні групи $2 / 8+3 / 8+3 / 8$ (№ 7 з першої серії і № 6 - з другої). «Звідси йде шлях до метроритму першої частини "Музики для струнних інструментів, ударних і челести", до танців в болгарських ритмах з "Мікрокосмосу" і до інших пізніших творів Бартока», - вважав I. Мартинов (1968: 79). Зауважимо, що примхливість ритму є суттєвою ознакою румунської музики. У записі пісень, наведеної в нотному виданні, видно, що в багатьох піснях відсутня квадратність, зате є змінність метра, складні ритмічні групи. При обробці народних наспівів композитор додатково ускладнює ритмічний малюнок, вводячи додаткові голоси 3 власним ритмом. Ця ритмічна «поліфонія пластів» народжує відчуття хисткості, легкості, імпровізаційності фактури і представляє значну складність для виконавця.

Цікаво відзначити й те, що в деяких виданнях «Румунських колядок» Б. Бартока існує концертний варіант «Appendix: versions for concert use», очевидно, розрахований на відгук публіки. Зміни в ньому стосуються лише восьми колядок (по чотири 3 кожного зошита). 3 першого зошита - №№ 3, 5, 6, 8, 3 другого - №№ 2, 4, 5, 7. У концертному варіанті фортепіанна фактура значно ускладнена за рахунок подвоєння мелодії в октавні унісони і акорди, що нагадує салонно-віртуозний стиль мистецтва ХІХ століття. 
Наприклад, колядка № 3 з першого зошита:

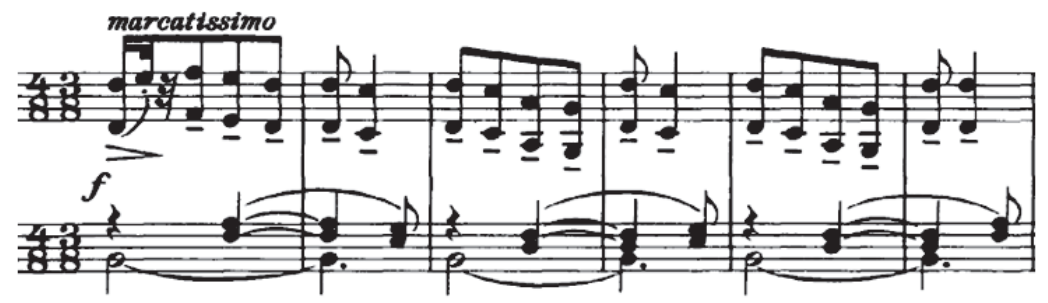

Партія лівої руки перенесена на октаву вниз, а тема подвоюється в октавний унісон. Також бачимо характерне для романтичної культури охоплення регістрів, що має ефект оркестрового звучання. Слід зазначити, що в такому варіанті неможливе беспедальне виконання, за принципом «звучить те, що можливо взяти руками». У новому концертом варіанті взяття педалі є обов'язковою умовою адекватної реалізації нотного запису.

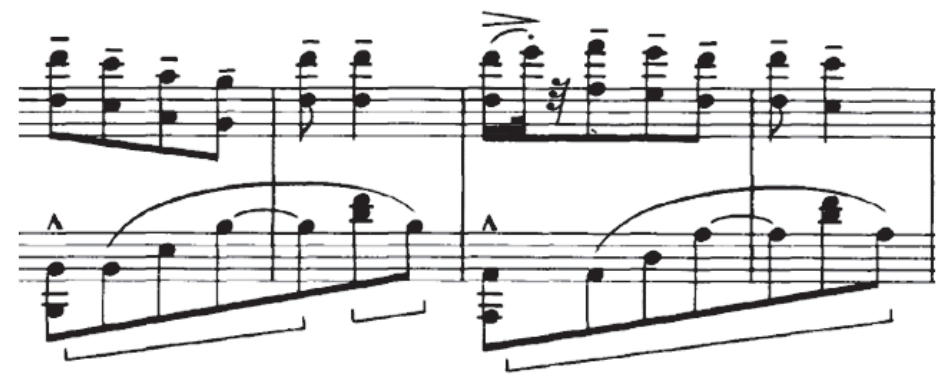

Позначимо виконавсько-стильові параметри «Румунських колядок» Б. Бартока. Про розвиток романтичної традиції свідчать: 1) технічно нескладне фортепіанне письмо, призначене для домашнього музикування, що зумовило малу форму, контрастність і різнохарактерність музичних образів; 2) створення циклу, який можна викону- 
вати на концертній естраді з характерними для романтизму технічними ефектами, розрахованими на реакцію публіки (подвійні ноти, регістрові стрибки, октавний рух).

Щодо неофольклорної тенденції маємо такі спостереження: 1) цикл створений на основі фольклорних тем з метою популяризації румунської музики; 2) реалізація завдання прочитання народної традиції дозволяє наблизити цю музику до молоді, зокрема, через виховання ладо-ритмічного слуху (своєрідні ладо-гармонічні та метро-ритмічні структури фортепіанного письма Бартока). На жаль, «Румунські колядки» мало знайомі вітчизняному слухачеві: виконання цього твору в Україні не відбулося. Тому заслуговує на особливу увагу діяльність угорського піаніста Золтана Кочіша, який у 2005 році завершив запис повного зібрання творів композитора для фортепіано. Можна стверджувати, що у піаніста є власне відчуття бартоківського піанізму як цілісної системи світовідчуття. У його виконанні «Румунські колядки» - яскравий зразок новітнього концертного стилю.

«Румунські танці»- ще одне втілення педагогічних і просвітницьких принципів Б. Бартока. Частини циклу мають програмні назви:

Joccubbrtă Танок $з$ палками - a-moll
1. Brabll
Танок з кушаком (коло) - d-moll
2. Peloc
Стрибковий танок (танець на місці) - h-moll
3. Buciumeana
Танок з Бучуна - A-dur
4. Poargă Rombnească
Румунська полька - D-dur
5. Măruntel
Швидкий танець - A-dur

«Румунські народні танці» Б. Бартока засновані на ритмо-мелодичних формулах, являючи чарівний світ румунського фольклору: від запальних швидких танців до ліричних імпровізацій. За жанровою будовою твір нагадує тип старовинної сюїти: перші два танці замінюють алеманду і куранти (перший - повільний, другий - швидкий), третій і четвертий - сарабанду (обидва повільні), яка є драматичним центром всього твору, а п'ятий і шостий - наче жига своєю швидкістю $з$ тенденцією на прискорення - завершує сюжет. Народна основа твору втілена через ударний піанізм; відсутність педалі; прозору 
фактуру; ясну вертикаль; тісне регістрове розташування. Фортепіанні п’єси орієнтовані на технічно не складне письмо, що обумовлює лаконізм, просту ритміку, контрастність образів. Цей цикл - вдала спроба максимально адекватної передачі на фортепіано звучання народних інструментів, що зумовило тембрально-колористичні рішення. Так, у танці № 2 можна почути «скрипкову» фактуру, в танці № 3 імітація тьмяного тембру флуера з майже безперервними форшлагами і мордентами.

«Румунські народні танці» Бартока були написані 3 метою домашнього музикування. В цьому сенсі вони співвідносяться 3 «Німецькими танцями» Л. Бетховена, «Норвезькими танцями» Е. Гріга, «Слов’янськими танцями» А. Дворжака. Музика «Румунських танців» відома в безлічі перекладень: для віолончелі, для різних інструментальних складів (для 15-ти саксофонів, ударних і фортепіано, для 7-ми кларнетів, флейти, гобоя, кларнета, фагота і валторни). Найпопулярніша версія - транскрипція для скрипки і фортепіано, зроблена відомим угорським скрипалем Золтаном Секей. Скрипалі навіть сперечаються про первинність версії для фортепіано і для скрипки, але насправді скрипкова версія ближче не до оригіналу, а до оркестрового перекладання, зробленого Б. Бартоком. Наприклад, і в оркестровій, і скрипковій версії № 2 і № 4 в мелодії повністю дубльовані в октаву.

Більшість фортепіанних творів Б. Бартока були написані в перші два періоди творчості - ранній і експериментальний. Увагу композитора було направлено на три сфери: фольклорну, педагогічну, новаторську семантику музичної мови, що, безумовно, впливали на якість фактури, віртуозності, формоутворення. Простежуються певні закономірності: схильність Б. Бартока до первинних (пісні, танцю) і романтичних жанрів (елегія, рапсодія, багатель), програмної циклічності; незмінний інтерес до створення дитячого репертуару, в якому вирішуються відразу два завдання: популяризація народної музики і залучення дітей до нового музичною мовою. Виконавський аналіз творів, створених Б. Бартоком в першому і другому періоді, не підтверджує думку деяких дослідників про кардинальну зміну звукового образу фортепіано з романтичного на ударно-беспедальний. 
Засаднича якість фортепіанного письма Б. Бартока - його національна характерність, оповита ресурсами новітньої музичної композиції. Бельгійський музикознавець Дені Ділла зберіг висловлювання Б. Бартока: «Моя гармонія всюди пристосовується до специфічного характеру використовуваних мною мелодій, незалежно від того, чи мають вони народне походження або були складені мною < ..> Я можу сказати, що і гармонія носить національний відбиток, проте не в такій мірі, як ритміка і мелодика моїх творів» (цит. за: Мартынов: 252).

Слуховий аналіз виконавського стилю Б. Бартока за існуючими аудіо-записами дозволяс зробити висновок, що на відміну від багатьох піаністів романтичної традиції, він дуже помірно користується педальними ефектами, віддаючи перевагу ясному і чіткому промовлянню всіх елементів фактури. Констатуємо вплив класичної традиції, що бере початок від клавесиністів, і нових течій, пов'язаних 3 ударним розумінням фортепіано. На грунті аналізу аудіо-записів Б. Бартока-піаніста виявлено ознаки його виконавського стилю:

1) просторове розмежування фактури, коли один звуковий шар навмисно «відсуваючи на задній план» нетематичні голосу (барокова традиція);

2) найтонша метроритмічна рухливість, що нівелює особливості акцентуації і туше, які не створюють враження ударності.

Незважаючи на всю емоційність і безпосередність вираження почуттів, Б. Барток відноситься до тих піаністів, у яких ratio відігравало найважливішу роль. У його виконавських концепціях чітко простежуються риси, характерні і для композиторського стилю - метроритмічна рухливість, хронотопічний метод творення форми, унікальне прослуховування фактури.

Усупереч поширеній думці про ударність фортепіанного стилю композитора і відмову від романтичної традиції в композиції, у виконавській діяльності Б. Барток застосовує багато чого з арсеналу романтиків. Перш за все, функцію педалі, навіть в тих власних творах, де вона не вказана. Хоча в фортепіанних п'єсах Б. Бартока є місця, які зіграти без педалі неможливо.

Висновки. Фортепіанне письмо Бели Бартока є увиразненням його новаційного композиторського мислення, в якому виконав- 
ська складова його власних можливостей відігравала ключову роль. Еволюцію фортепіанного стилю Б. Бартока слід розглядати як рух від романтичної парадигми мислення - через фольклоризм - до неокласичного синтезу. Цей рух легко простежується «на слух» завдяки змінам в системі музично-мовних ресурсів (ритм, гармонія, музична форма, фактура, мелос). Як наслідок, змінювався і звуковий образ фортепіано, що отримав стильову атрибуцію «бартоківський».

Основні чинники ладо-гармонічного стилю Бартока (опора на старовинні лади народної музики; ладова змінність в умовах хроматичної тональності) визначають труднощі засвоєння «інтонаційного словника» його творів, і в цілому високотехнічну оснащеність фортепіанної фактури. Рівень володіння інструментом у Б. Бартока, з одного боку, був віртуозно-граничний, а 3 іншого - декламаційно-мовленнєвий $\mathrm{i}$, головне, доступний великому колу любителів музики. Новаційність фортепіанного письма Бартока стосувалась його відчуття музичного часопростору, що змінило уявлення про становлення форми як процесу. 3 точки зору часової організації його твори відрізняють метрична змінність і поліритмія; часова розбіжність фактурних пластів; широке використання репетиційної техніки і прийомів ostinato. Отже, прийшов час по-новому оцінити творчість Б. Бартока, знявши з нього кліше експериментатора, розгледіти й ті риси стилю, які вказують на його приналежність до «золотого фонду» музичної традиції XX століття, що в час глобалізації становить класику світової культури.

\section{ЛИТЕРАТУРА}

Андреева, Е. (2013). Темпоральное мышление Б. Бартока и Д. Лигети в свете диалога востока и запада (Автореф. дисс. ... канд. искусствоведения). Саратов, 20.

Беляев, В. (1929). Барток в Москве. Жизнь искусства. № 6.

Буш, А. (1938). Современные течения западной музыки. Советская музыка. № 12. 93-101.

Веллес, Э. (1925). Струнные квартеты Бартока. Современная музыка. № 7.

Деревянченко, Е. (2005). Неофольклоризм в музыкальном искусстве: статика и динамика развития в первой половине XX века (Автореф. дисс. ... канд. искусствоведения). Киев, 20. 
Глебов, И. (1925). Барток. Красная газета. № 118.

Гаккель, Л. (1976). Фортепианная музыка XX века: очерки. Ленинград: Сов. композитор, 296.

Нестьев, И. (1969). Бела Барток: жизнь и творчество. Москва: Музыка, 800.

Малинковская, А. В. (1985). Бела Барток - педагог. Москва: Музыка, 102.

Мартынов, И. (1968). Бела Барток. Москва: Сов. композитор, 288.

Мартынов, И. (1956). Бела Барток: Очерк жизни и творчества. Москва: Музгиз, 168.

Сигитов, С. (1971). Этапы творческой эволюции Бартока. Из истории музыки ХХ века. Москва: Музыка, С. 189-207.

Чижик, И. (1981). Ладоритмические закономерности музыки Б. Бартока (Автореф. дисс. ... канд. искусствоведения). Киев, 24.

Чинаев, В. (1995). Исполнительские стили в контексте художественной культуры XVIII-XX веков (на примере фортепианного исполнительского искусства) (Автореф. дисс. ... доктора искусствоведения). Москва, 48.

Szabolcsi, B. (1963). Mensch und Natur in Bartyks Geisteswelt. Studia Musicologica. T. V., Budapest.

Ujfalussy, J. (1965). Einige inhaltliche Fragen der Bruckensvmmetrie in Bartyks Werken. Liszt - Bartyk. Budapest.

\section{REFERENCES}

Andreeva, E. (2013). Temporalnoe myshlenye B. Bartoka i D. Lyhety v svete dyaloha vostoka y zapada [Temporal Thinking of B. Bartok and D. Ligeti in the Light of the Dialogue between East and West]. (Extended abstract of Candidate thesis). Saratov, 20 [in Russian].

Beliaev, V. (1929). Bartok v Moskve [Bartok in Moscow]. Zhyzn yskusstva. № 6 [in Russian].

Bush, A. (1938). Sovremennye techenyia zapadnoi muzyki [Contemporary Western Music Trends]. Sovetskaia muzyka. № 12. 93-101 [in Russian].

Velles, Э. (1925). Strunnye kvartety Bartoka [Bartok String Quartets]. Sovremennaia muzyka. № 7 [in Russian].

Derevianchenko, E. (2005). Neofolkloryzm v muzykalnom yskusstve: statyka $y$ dynamyka razvytyia $v$ pervoi polovyne XX veka [Neo-folklorism in the art of music: statics and dynamics of development in the first half of the twentieth century]. (Extended abstract of Candidate thesis). Kyiv, 20 [in Russian]. 
Hlebov, Y. (1925). Bartok. Krasnaia hazeta. № 118 [in Russian].

Hakkel, L. (1976). Fortepyannaia muzyka XX veka: ocherky [Piano Music of the 20th Century: Essays]. Lenynhrad: Sovetskij kompozitor, 296 [in Russian].

Nestev, Y. (1969). Bela Bartok: zhyzn y tvorchestvo [Bela Bartok: life and works]. Moscow: Muzyka, 800 [in Russian].

Malynkovskaia, A. V. (1985). Bela Bartok-pedahoh [Bela Bartok is a teacher]. Moscow: Muzyka, 102 [in Russian].

Martynov, Y. (1968). Bela Bartok. Moscow: Sovetskij kompozitor, 288 [in Russian].

Martynov, Y. (1956). Bela Bartok: Ocherk zhyzny y tvorchestva [Bela Bartok: An Essay on Life and Works]. Moscow: Muzghyz, 168 [in Russian].

Syhytov, S. (1971). Etapy tvorcheskoi evoliutsyy Bartoka. Yz ystoryy muzyky XX veka [The stages of Bartok's creative evolution. From the history of 20th century music]. Moscow: Muzyka, 189-207 [in Russian].

Chyzhyk, Y. (1981). Ladorytmycheskye zakonomernosty muzyky B. Bartoka [Fret-rhythmic patterns of B. Bartok's music]. (Extended abstract of Candidate thesis). Kyev, 24 [in Russian].

Chynaev, V. (1995). Yspolnytelskye styly v kontekste khudozhestvennoi kultury XVIII-XX vekov (na prymere fortepyannoho yspolnytelskoho yskusstva) [Performing Styles in the Context of Artistic Culture of the 18th - 20th Centuries (on the Example of Piano Performing Arts)]. (Extended abstract of Doctoral thesis). Moscow, 48 [in Russian].

Szabolcsi, B. (1963). Mensch und Natur in Bartyks Geisteswelt. Studia Musicologica. T. V., Budapest [in German].

Ujfalussy, J. (1965). Einige inhaltliche Fragen der Bruckensvmmetrie in Bartyks Werken. Liszt - Bartyk. Budapest [in German]. 